\title{
Effect of Biochar on Chemical Behavior and Radish Plant Uptake of Heavy Metals Grown in Polluted Soils
}

\author{
Laila R. Salem ${ }^{1 *}$, Maher E. Saleh ${ }^{2}$, Dina S. Abu-Elnine ${ }^{1}$
}

\begin{abstract}
In this research, we studied the effect of sugarcane bagasse biochar (SCBB) on the chemical behavior of $\mathrm{Zn}$, $\mathrm{Ni}, \mathrm{Cr}$, and $\mathrm{Cu}$ through speciation experiment in two contaminated soils from Alsharqia governorate soil $\mathrm{A}$, and from Burg El-Arab (Alexandria Governorate) as soil B. In addition to, investigate bioavailability of these metals in soil after soil treatment with different rates of biochar $(0.5$, 1, and 2\%) via pot experiment using radish plant (Raphanus sativus) as a bio-indicator. The results showed that exchangeable, carbonate and oxides-bound fractions decreased with increase biochar dosage. However, the residual and organic fractions increased. Bioavailability of $\mathrm{Zn}, \mathrm{Ni}, \mathrm{Cr}$, and $\mathrm{Cu}$ decrease with increasing biochar application rate. Thus, the heavy metals concentrations in shoot and root decreased with increasing biochar dosage., for example in soil $A$ when biochar dosage was $1 \%$ the percentage decrease of $\mathrm{Zn}, \mathrm{Cu}, \mathrm{Ni}$, and $\mathrm{Cr}$ in shoot was $8.63,6.25,47.15$, and $35.02 \%$ respectively. It can be suggested that high surface area and surface functional groups of biochar played an important role in fixation and stabilization of heavy metals in the forms of organic and residual fractions in soils.
\end{abstract}

Keywords: Sugarcane bagasse biochar, contaminated soils, heavy metals fractionation, bioavailability

\section{INTRODUCTION}

Contaminated soils with heavy metals are found due to mining activity, emission of industrial wastes and irrigation with wastewater (Mench et al., 2010). Pollution of soil with heavy metals causes many problems such as decrease in soil fertility and grain yield, more over pollution of surface water. Therefore, reach to animal and human through food chain and threaten their life (Fellet et al., 2014) in addition to nonbiodegradable and toxic nature of heavy metals (Niazi et al., 2017). Soil and water contamination with heavy metals effect on crop yield and plant growth for instance due to the high concentration of trace metals in wastewater (Alghobar and Suresha, 2016) reported lowering in growth and yield of rice crop. According to (Zhou et al., 2016), six vegetable types were cultivated on farmland contaminated with heavy metals $(\mathrm{Pb}, \mathrm{Cd}$, $\mathrm{Cu}, \mathrm{Zn}$, and $\mathrm{As}$ ), the result showed that the ability of leafy vegetables to uptake and accumulate heavy metals was the highest, and this caused health risks due to vegetables consumption.

Immobilization of heavy metals and reducing their accumulation in plants by organic and inorganic amendments was studied by many authors (Rajkovich et al., 2012; Lu et al., 2017; Mehmood et al., 2017; Meng et al., 2017). Immobilization of heavy metals can be done by application of stabilization materials in soil, which can adjust or change proportion of bioavailable fraction of heavy metals that reduce biological availability and mobility of heavy metals in soil environment (Cao and Dai, 2011).

Biochar is considered an important stabilization material. Several studies illustrated that biochar can make stabilization to heavy metals in soils (Cao et al., 2009; Lehmann and Joseph, 2009). Stabilization of heavy metals by biochar depends on its surface reactivity (functional groups), so transition and nontransition metals can be sorbed on to biochar surface (Amonette and Joseph, 2009). Biochar is a carbon-rich pyrolysis product manufactured under oxygen-deficient or no-oxygen conditions $\left(300-700{ }_{\circ} \mathrm{C}\right)$ and, it is a kind of environmentally friendly, economicand renewable material (Chaosheng et al., 2018). Three kinds of feedstock substances can be used to produce biochar, plant residue, animals litter, and sewage sludge (Srinivasan et al., 2015).

Biochar production is not an important way to remediate soil pollution only but also it is a good way to get ride off wastes in benefit way. Where we are facing some problems in accumulation of agricultural wastes and how we can optimal use of it. The annual quantity of agricultural waste in Egypt reach 35 million tons, of which only $18 \%$ is used as fertilizer (El-Mashad et al., 2003 and Rashad et al., 2019). Addition of biochar to mine soil contaminated with heavy metals decreased the content of available $\mathrm{Cd}, \mathrm{Pb}$ and $\mathrm{Zn}$. Moreover, application of biochar during mine soil remediation could reduce plant concentrations of heavy metals in addition to symptoms of heavy metal toxicity were absent in plants growing in soil treated with biochar (Puga et al., 2015a). 
Biochar is favorable material than organic materials because heavy metals retained by biochar will be released more slowly than other retained by fresh organic materials, which decompose rapidly (Tang et al., 2013). When raw organic materials turn into biochar through pyrolysis processes, many changes in chemical and physical properties will be done. These properties increase the affinity of biochar to retain heavy metals and remediate polluted soils (Agrafioti et al., 2013; Zhang et al., 2013; Trakal et al., 2014). Harvey et al., 2011 and Zhang et al., 2017 demonstrated that biochar structure has high degree of aromatization, providing $\pi$ electrons that could strongly bond heavy metal cations.

Wastewater contains many organic and inorganic pollutants. In Egypt,Sahl El Husseiniya region, AlSharqia governorate, agricultural soil is irrigated with wastewater from Baher El Baqar drain that causes contaminating of this soil by heavy metals. Baher ElBaqar drain is located at the east of Nile Delta and it is starting from east of Cairo and pours into El-Manzala Lake. Abdel-Fattah and Helmy (2015) mentioned that58percentage of the total wastewater of Bahr ElBaqar drain comes from agricultural drainage, $2 \%$ from industrial wastes and around $40 \%$ from municipal and commercial drainage.

In Egypt, sugar production from sugarcane crop is one of the oldest industries. Sugarcane plantations are concentrated in the Upper Egypt specifically in Menia, Sohag, Qena, Luxor and Aswan governorates. The total amount of sugarcane cultivated in Upper Egypt is about 16 million tons per year (Chauhan et al., 2011).

The percentage of by-products and co-products generated during the sugar production process are as follows: $30 \%$ bagasse, $3.5 \%$ Filter mud/cake and $0.4 \%$ Furnace ash. Bagasse reuse in power generation and production of paper and fiberboard (Nakhla and Haggar, 2014). Utilization of sugarcane bagasse in producing biochar is considered a new approach to get rid of this waste( Saleh and Hedia, 2018).

The objectve of this study was to provide an overview on the effect of sugarcane bagasse biochar on the behavior and plant uptake of heavy metals grown in contaminated soils from Alsharqia governorate and Burg Al Arab area, and also to demonstrates the potential of using biochar for remediation of polluted soils.

\section{MATERIAL AND METHODS}

\section{$\underline{\text { Soil collection and characterization }}$}

Two soil samples were collected at 0-20 depth named (soil A) from Alsharqia governorate within latitude $30^{\circ} 50^{\prime} 48^{\prime \prime} \mathrm{N}$ and longitude $31^{\circ} 58^{\prime} 53^{\prime \prime} \mathrm{E}$, mainly irrigated with wastewater from Bahr El-Baqar drain and (soil B)from Burg Al Arab area in latitude 30 $53^{\prime} 13^{\prime \prime} \mathrm{N}$ and longitude 29 $9^{\circ} 36^{\prime} 36^{\prime \prime}$ E. Second industrial area. The industrial activities in in Burg Al Arab are mainly food processing, detergents manufacturing, and textile. These two soils have been polluting with heavy metals (EL-Bady, 2014). Soil pH and electrical conductivity (EC)were measured in soil suspension $(1: 2.5 \mathrm{w} / \mathrm{v})$ (Black, 1965). Cation exchange capacity (CEC) was measured using sodium acetate method. Soil organic carbon (SOC) was determined by WalkleyBlack method (Black, 1965). DTPA-extractable of heavy metals was determined according to (Lindsay and Norvell, 1978) in soils $\mathrm{A}$ and $\mathrm{B}(\mathrm{Fe}, \mathrm{Zn}, \mathrm{Mn}, \mathrm{Cu}$, $\mathrm{Cr}, \mathrm{Ni}$ and $\mathrm{Co}$ ) were determined and measured by ICP (Inductively coupled plasma-mass spectrometry).Total heavy metals were determined according to the method described by Ure (1995)and measured by ICP (Inductively coupled plasma-mass spectrometry).

\section{Preparation of Biochar:}

Biochar was prepared from feedstock of sugarcane bagasse (SCBF). The raw materials (SCBF) in this study were collected from the nearest cane juice stores and were washed with tap and then distilled water several times to remove dust and impurities then dried at $80{ }^{\circ} \mathrm{C}$ for 24 hours. Pyrolysis process was carried out using traditional method (El Gamal et al., 2017) at around $500{ }^{\circ} \mathrm{C}$ for two hrs. After cooling biochar sample was washed with distilled water then dried at $105{ }^{\circ} \mathrm{C}$ for 5.0 hours. After cooling, biochar sample was crushed and sieved using $0.5-\mathrm{mm}$ polypropylene sieve.

\section{Characterization of Biochar}

Characterization of sugarcane bagasse biochar (SCBB) sample involved $\mathrm{pH}$ and EC determination at the ratio 1:20 w/v (biochar/water suspension), specific surface area measurement by the $\mathrm{N}_{2}$ - BET method and CEC determination according to Song and Guo (2012). Fourier transform infrared (FTIR) is used to determine surface functionalgroups, whichwere determining by scanning SCBB with infrared rays in the range $400-$ $4000 \mathrm{~cm}^{-1}$ using SHEMATZU infrared spectrophotometer model FT/IR5300, JASCO Corporation, Japan. And the ash was determined according to (Samsuri et al., 2014). The scanning electron microscopy (SEM) was carried out for biochar sample using SEM Quanta FEG Unit, with accelerating voltage 30 k.v., (magnification 250x up to 20000 0061nd resolution for Gun. $1 \mathrm{~m}$ ).

\section{Planting experiment}

Three $\mathrm{kg}$ soil mixed (or not) with either $0.5 \%, 1 \%$, or $2 \%$ SCBB they transferred into plastic pots in three replicates to each biochar treatment for the two soils A and $\mathrm{B}$. Treatments without biochar $(0 \%$ biochar) were regarded as the control. The pot experiment was conducted using radish plant (Raphanus sativus) as a bio indicator for environmental pollution (Davies, 1993; 
Hassan et al., 2018). Five seeds were sown in each pot and water was added to bring the soil moisture to $70 \%$ of water holding capacity. Thus, there were three replicates of each treatment giving 24 pots for each soil. The plants were harvested 40 days after sowing.

\section{Soil analysis and chemical fractionation}

After plant harvest, the soil content of each pot was air dried, crushed and sieved $(<0.5 \mathrm{~mm})$ and chemically analyzed for determined the amount of available using (DTPA method) according to (Lindsay and Norvell, 1978) and total heavy metals $\mathrm{Zn}, \mathrm{Cu}, \mathrm{Cr}$, and $\mathrm{Ni}$ (Ure, 1995). The rhizosphere soil was used for chemical fractionation. The sequential extract method (Tessier et al., 1979) was used to determine the speciation of heavy metals in the two soils A and B in control and SCBBtreated soils. The fractions were separated into exchangeable, carbonate, oxides, organic and residual fractions. Heavy metals content was determined by ICP (Inductively coupled plasma-mass spectrometry).

plant analysis

Radish plant shoot was cut just $2 \mathrm{~cm}$ above the soil surface, washed in taps water then by distilled water. Plant roots were separated gently from soil with portion of soil. Then washed in tap and distilled water. Plant shoot and root were oven dried for 48 hours at $70{ }^{\circ} \mathrm{C}$ and then ground in stainless steel mill before digestion. Plant shoot and root and were wet digested according to Jones (1989). Through filtered 0.45-mm membranes (GelmanSciences, USA) and the concentration of heavy metals were determined in the filtrate by ICP-MS.

\section{Statistical Analysis}

The significance test was carried out using ANOVA test, the least significant difference test (L.S.D) at 0.05 and 0.01 levels of probability according to Steel et al. (1997). On the other hand, Pearson's correlation coefficient, were performed for a better understanding of the relationship among the measurements of the two soils using the computer software program PAST version 4.03 (Hammer et al., 2020).

\section{RESULTS AND DISCUSSION}

\section{Characterization of studied soils}

Table 1 showed that the texture of two studied soil are sandy clay loam with increase in clay fraction in soil A than soil B. Also organic matter in soil A is greater than in soil B, these results may cause increase in cation exchange capacity in soil A (10.70 meq/100g soil) than in soil B $(9.73 \mathrm{meq} / 100 \mathrm{~g}$ soil). However, the total carbonate in soil B is greater than in soil A. This mainly attributed to the natural and composition of the parent material of Burg Al-Arab soil. Thus soil B is more alkaline $(\mathrm{pH}=8.66)$ than soil $\mathrm{A}(\mathrm{pH}=7.75)$ (Wali et al., 2013). EC values are $2.55 \mathrm{dS} / \mathrm{m}$ and $2.63 \mathrm{dS} / \mathrm{m}$ in soil A and B, respectively. Table (2) showed available and total heavy metals in both soils. The data illustrated that soil $\mathrm{A}$ and $\mathrm{B}$ are considered polluted with $\mathrm{Zn}, \mathrm{Cu}, \mathrm{Ni}$, $\mathrm{Mn}$ and Fe according to WHO (1996).

\section{Characterization of biochar}

Tables 2 and 3 illustrate some properties of biochar as $\mathrm{pH}, \mathrm{EC}$ and elemental contents of $\mathrm{H}, \mathrm{N}, \mathrm{C}$, and $\mathrm{S}$ with the predominant amount of $\mathrm{C}$, and heavy metals contents. In addition, the surface area and CEC, FTIR of SCBB is present in Fig (1) which, based on the absorption of the infrared radiation at certain frequencies and allowed conclusions on the functional groups on the biochar surface.

Ten radiation spectra in the range of $4000-400 \mathrm{~cm}^{-}$ ${ }^{1}$ were obtained to biochar sample. Peak at $3430.51 \mathrm{~cm}^{-}$ ${ }^{1}$ informing the presence of $\mathrm{H}$ bond. This band confirms the presence of hydroxyl (OH-), ammonium, or amino. In addition, the existence of spectra at frequencies of $1602.90,786.02$, and 673.18 confirmed the presence of hydroxyl compound (Sahu et al., 2010). Peak below $3000 \mathrm{~cm}^{-1}$ showing aliphatic compound (aliphatic C-H) which indicates the presence of alkane functional group (Nandiyanto et al., 2019), for example peaks at 2942.15 and $2315.30 \mathrm{~cm}^{-1}$ show (asymmetric C-H stretching) and this confirmed by the presence of $1426.41 \mathrm{~cm}^{-1}$, $1420.62 \mathrm{~cm}^{-1}$ and $786 \mathrm{~cm}^{-1}$. The presence frequencies of $2000 \mathrm{~cm}^{-1}$ and $2500 \mathrm{~cm}^{-1}$ refer to triple bond region ($\mathrm{C} \equiv \mathrm{C}$-), as in $2351.30 \mathrm{~cm}^{-1}$ and this confirmed by 1600 $\mathrm{cm}^{-1}-1300 \mathrm{~cm}^{-1}$ as, 1602.96, 1426.41, $1420.62 \mathrm{~cm}^{-1}$ (Nandiyanto et al., 2019). The peaks $1500-2000 \mathrm{~cm}^{-1}$ showed the presence of double bond $(\mathrm{C}=\mathrm{C}, \mathrm{C}=\mathrm{N}$, and $\mathrm{N}=\mathrm{N}$ groups as in $1602.90 \mathrm{~cm}^{-1}$ below $1700 \mathrm{~cm}^{-1}$ replying amides or carboxylates function group as in $1602.90 \mathrm{~cm}^{-1}$, and $1602.90 \mathrm{~cm}^{-1}$ inform double bond or aromatic compounds. Area around 786.02 and 673.18 $\mathrm{cm}^{-1}$ represent C-H aromatic compound and alkyl bind. In addition, it can be interpreted as $\mathrm{Si}-\mathrm{O}-\mathrm{Si}$ and $\mathrm{Si}-\mathrm{H}$ reactive groups (Saleh et al., 2014).

As shown in Fig. (2), scanning electron microscope (SEM) images showed the surface morphology of biochar sample. It is clear that biochar surface contains many pores and canals with smooth surface and different size, which may be developed due to the thermal decomposition 
Table 1. Some chemical and physical properties of soils used in the study

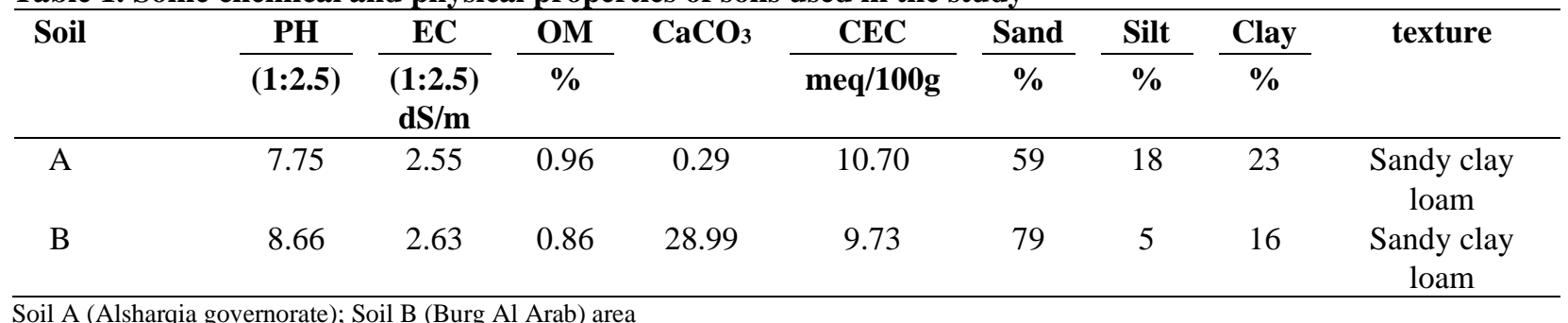

Table 2. The amount of total and available content of heavy metals in soil A, soil B and SCBB

\begin{tabular}{cccc}
\hline & Soil A & Soil B & Biochar \\
\hline Total content of heavy metals mg.kg-1 & & & \\
\hline $\mathrm{Zn}$ & 182.25 & 142.25 & 127 \\
$\mathrm{Ni}$ & 75.25 & 78.00 & 8.90 \\
$\mathrm{Co}$ & 16.55 & 10.73 & - \\
$\mathrm{Cr}$ & 60.89 & 68.00 & - \\
$\mathrm{Mn}$ & 174.15 & 120.35 & 40.00 \\
$\mathrm{Cu}$ & 57.68 & 58.72 & 16.21 \\
$\mathrm{Fe}$ & 5005 & 5962 & 2480 \\
& & & \\
DTPA extractable heavy metals mg.kg-1 & & & 1.80 \\
$\mathrm{Zn}$ & & & 0.07 \\
$\mathrm{Ni}$ & 40.12 & 20.42 & 0.10 \\
$\mathrm{Co}$ & 17.61 & 10.54 & 0.21 \\
$\mathrm{Cr}$ & 15.44 & 4.94 & 0.72 \\
$\mathrm{Mn}$ & 11.74 & 5.00 & 0.14 \\
$\mathrm{Cu}$ & 17.93 & 10.51 & 2.91 \\
$\mathrm{Fe}$ & 10.98 & 6.44 & \\
\hline
\end{tabular}

Table 3. Sugarcane bagasse biochar (SCBB) characteristics

\begin{tabular}{|c|c|c|c|c|c|c|c|c|}
\hline \multirow{2}{*}{$\begin{array}{l}\mathrm{pH}^{*} \\
1: 20\end{array}$} & EC** & $\mathrm{C}$ & $\mathbf{H}$ & $\mathbf{N}$ & $\mathbf{S}$ & \multirow{2}{*}{$\begin{array}{c}\mathrm{SA} \\
\mathrm{cm}^{2} / \mathrm{g}\end{array}$} & \multirow{2}{*}{$\begin{array}{c}\text { CEC } \\
\text { meq/100g }\end{array}$} & \multirow{2}{*}{$\begin{array}{c}\text { ASH content } \\
\%\end{array}$} \\
\hline & $\begin{array}{r}1: 20 \\
d S / m\end{array}$ & \multicolumn{4}{|c|}{$\%$} & & & \\
\hline 6.61 & 0.43 & 54.64 & 5.13 & 0.36 & 0.21 & 46.98 & 48.30 & 19.86 \\
\hline
\end{tabular}

** In 1:20 biochar water extract

cellulose and hemicelluloses and left of lignin, which is a very resistant to thermal degradation (Novotny et al., 2015). These results are in agreement with these obtained by El-Damarawy et al.. (2017).

Effect of biochar application on heavy metals speciation in soil

Figure 3 show the five fractions of $\mathrm{Zn}, \mathrm{Cu}, \mathrm{Ni}$ and $\mathrm{Cr}$ in soil after plant harvest with and without biochar treatment at different dosage of SCBB. As showed in the figure, the predominant fraction in the control of the two studied soils is residual fraction for three metals $\mathrm{Cr}$, $\mathrm{Zn}$ and $\mathrm{Cu}$, followed by carbonate fraction in soil $\mathrm{B}$. However, for $\mathrm{Ni}$, the predominant fraction was carbonate in soil B. After treatment, the percentage of residual fraction increased in the two soils for all elements followed by organic fraction. 
由 SHIMADZU

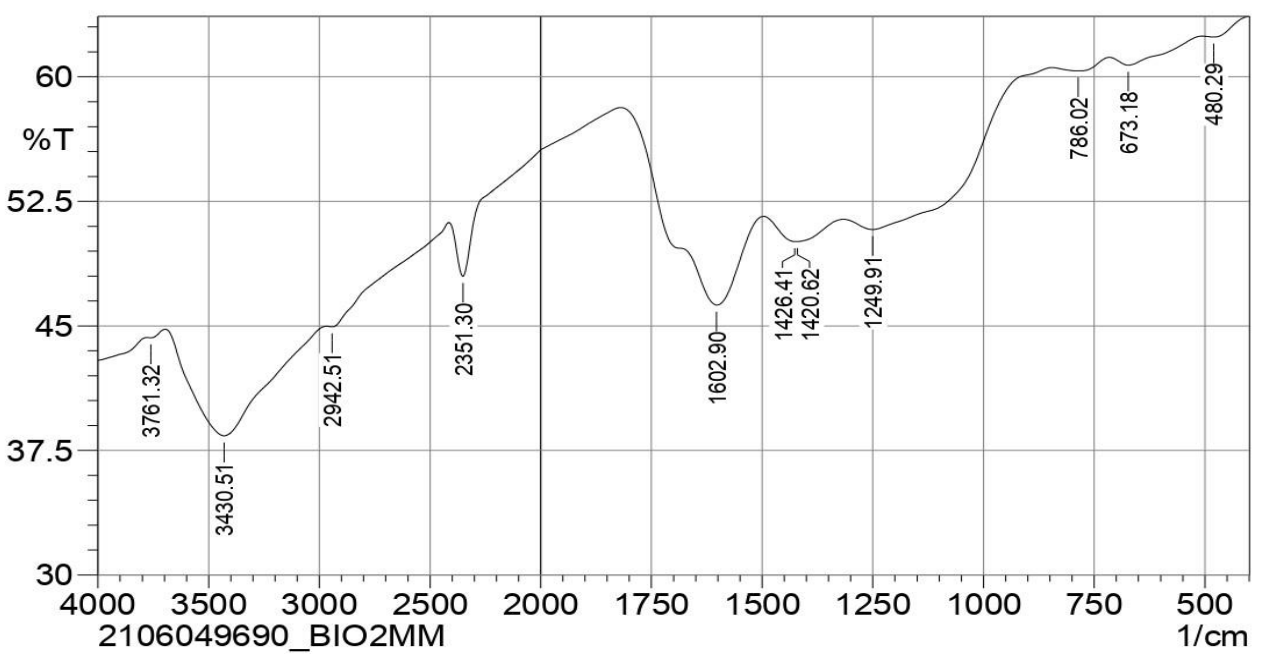

Fig. 1. Fourier-transform infrared spectra (FTIR) of the SCBB sample

\section{Chromium}

As shown in Fig 3 in soil A it is clear that exchangeable, carbonate and oxides-bound fractions of Cr decreased with increasing biochar dosage by 92.43 , 63.68 and $39.14 \%$ for 2,1 and $0.5 \%$ of applied SCBB, respectively. For exchangeable fraction, by $26.57,7.11$ and $5.93 \%$, for 2,1 and $0.5 \%$ of applied SCBB, respectively, for carbonate fraction, by $15.33,12.24$ and 7.82 for 2,1 and $0.5 \%$ of SCBB, respectively, for oxidebound fraction. Same trends were observed in soil B where the exchangeable fraction decreased by 90.63 , $57.85,11.07 \%$ for 2,1 and $0.5 \%$ of applied SCBB, respectively. On the other hand, carbonate fraction decreased by $44.22,26.39$ and $23.45 \%$ for 2,1 and $0.5 \%$ of SCBB dosage, respectively. The oxides-bound fractions of $\mathrm{Cr}$ decreased by $42.22,24.93$ and $15.14 \%$ for 2, 1, 0.5\% of applied SCBB, respectively (Fig. 3).

Organic and residual fractions increased with increasing biochar dosage. For organic fraction, the increase was by $35.61,30.24$ and $17.33 \%$ for 2,1 and $0.5 \%$ of applied SCBB, respectively, compared to the control. The residual fraction increased by increasing biochar dosage by $3.13,2.07$ and $1.42 \%$ for 2,1 and $0.5 \%$ biochar respectively, this was for soil A. In soil B, the organic fraction increased by $32.41,26.79$ and
$5.62 \%$ for $2 \%, 1 \%$ and $0.5 \%$ biochar respectively. In addition, the residual fraction increased by $4.97 \%$, $2.83 \%$ and $2.71 \%$ for $2 \%, 1 \%$ and $0.5 \%$ biochar dosage respectively (Fig. 3).

Zinc

Figure (4) illustrates the changes in zinc fractions as results of SCBB application to the two soils. The predominant $\mathrm{Zn}$ fraction in soil $\mathrm{A}$ is residual fraction followed by fractions bonded to oxides and organics. It is clearly that exchangeable, carbonate, and oxidesbound fractions decreased by increasing biochar dosage. For exchangeable fraction, the decrease was by 80.41 , 29.55 and $25.82 \%$ for 2,1 and $0.5 \%$ of SCBB dosage, respectively. For carbonate fraction, the percentage of decrease was by $11.83,28.25$ and $18.61 \%$ for 2,1 and $0.5 \%$ biochar treatment, respectively. For fraction of oxides-bound $\mathrm{Zn}$, the decreases were by $35.75,5.94$ and $5.74 \%$ for 2,1 and $0.5 \%$ biochar dosage, respectively. In soil $\mathrm{B}$ the predominant fraction was the residual followed by carbonate fraction then oxides-bound $\mathrm{Zn}$. The decrease in exchangeable, carbonate, and fraction bound to oxides was by $95.25,86.12$ and $55.13 \%$, $33.37,16.10$ and $11.42 \%, 24.81,6.30$ and $7.54 \%$ for $2 \%, 1 \%$ and $0.5 \%$ biochar treatments, respectively. 


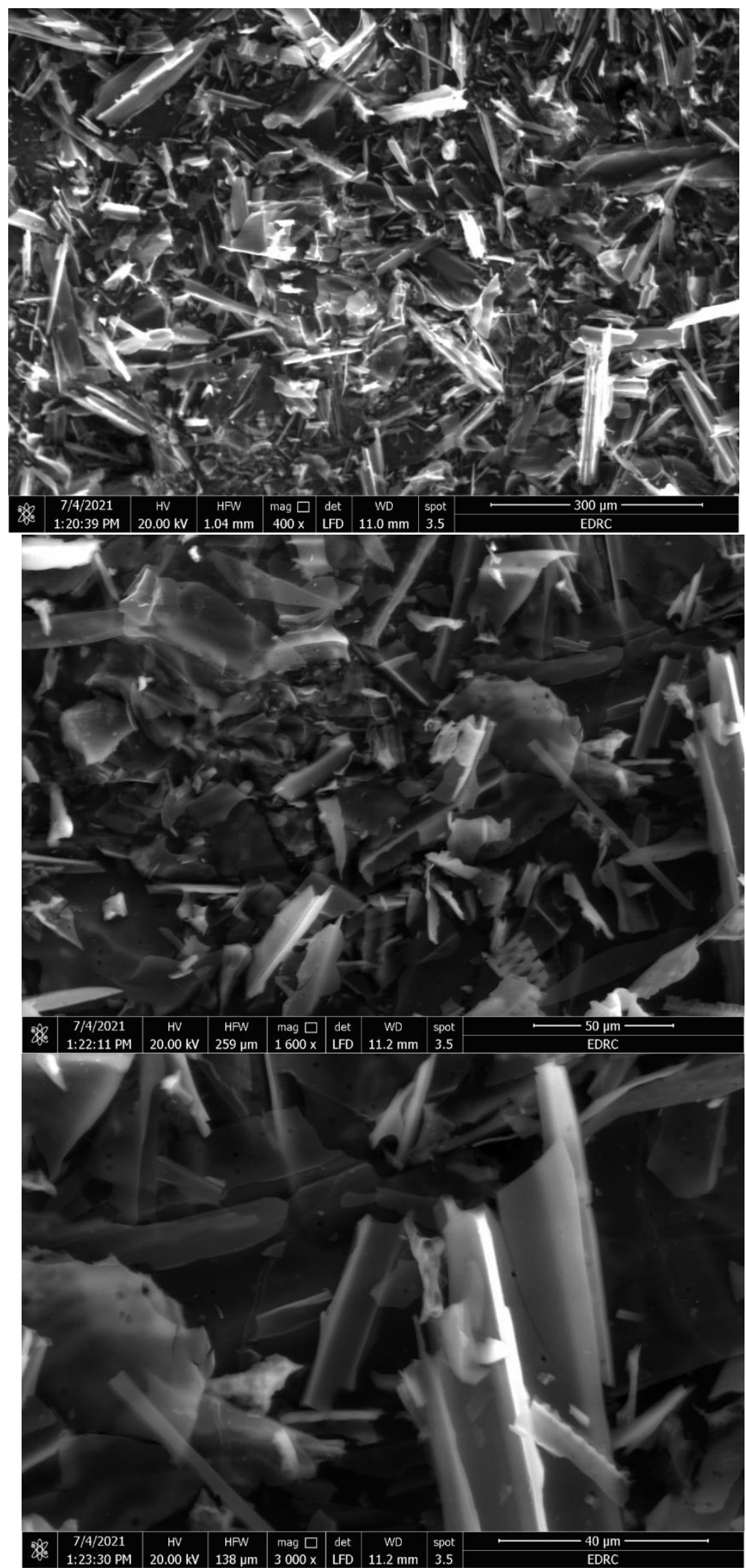

Fig. 2. Scanning electron microscope (SEM) images of sugarcane bagasse biochar (SCBB) 

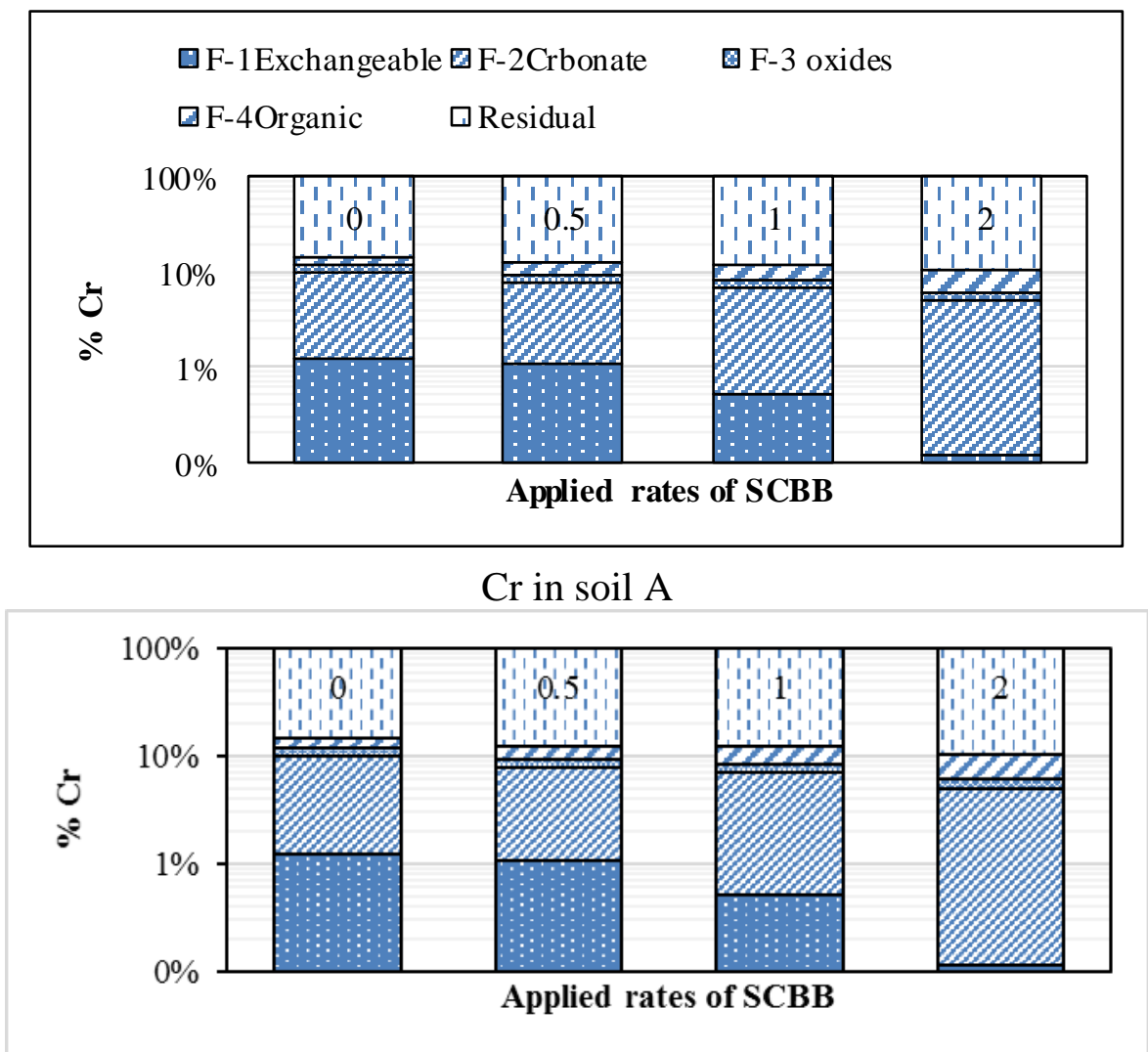

$\mathrm{Cr}$ in soil B

Fig.3. Changes in soil chromium fractions as result of sugarcane bagasse biochar (SCBB) application rate to the two soils $A$ and $B$ after plant harvest

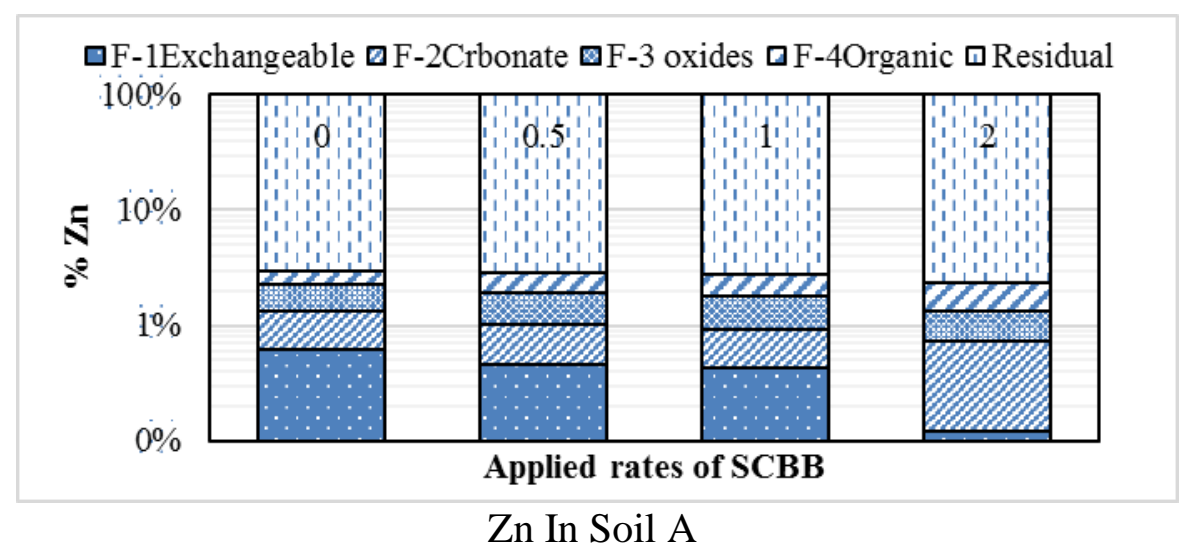




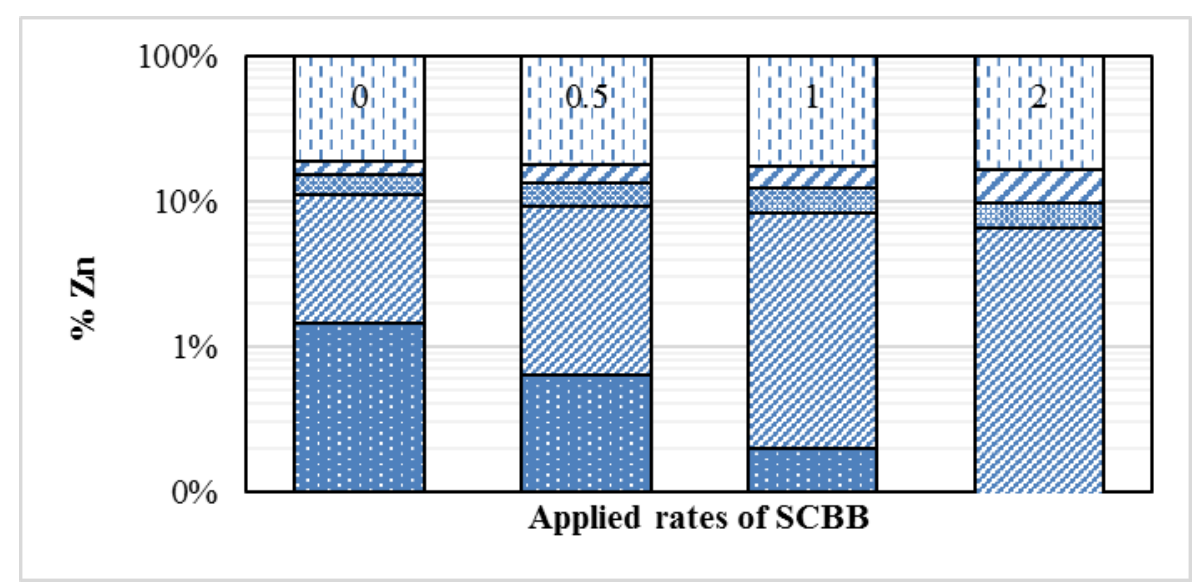

Zn in Soil B

Fig.4. Changes in soil zinc fractions as result of sugarcane bagasse biochar (SCBB) application rate to the two soils $A$ and $B$ after plant harvest

However, there were increases in the organic and residual fractions by $27.45,20.10$ and $19.37 \%$ and 0.63 , 0.38 and $0.16 \%$ for 2,1 and $0.5 \%$ biochar dosage, respectively, in soil A. The increase percentages in soil $\mathrm{B}$ for organic and residual fraction were by $50.32,33.11$ and $24.44 \%$ and $2.76,1.67$ and $1.36 \%$ for 2,1 and $0.5 \%$ biochar treatment, respectively.

Nickel

Figure (5) showed that the main $\mathrm{Ni}$ fraction is the residual followed by fractions bound to organics, carbonate and oxides. In soil $\mathrm{A}$, the decreases in exchangeable, carbonate and oxides-bound fractions due to the addition of biochar was by $67.72,64.46$ and $5.6 \%, 36.00,29.12$ and $12.68 \%, 43.94,38.07$ and $4.40 \%$ for $2 \%, 1 \%$ and $0.5 \%$ biochar dosage, respectively. In soil B Ni found mainly in carbonate fraction followed by residual, organic and oxides-bound. The exchangeable, carbonate and oxide fractions decreased by $62.31,61.06$ and $46.57 \%, 38.64,29.02$, and $24.21 \%$, $50.48,53.64$ and $44.56 \%$ for $2 \%, 1 \%$ and $0.5 \%$ SCBB dosage. On the other hand, addition of biochar caused increase in organic and residual fraction by $23.80,18.71$ and $13.00 \%, 25.83,4.16$ and $16.15 \%$ for $2 \%, 1 \%$ and $0.5 \%$ of applied biochar, respectively in soil A. Results of soil B showed that organic and residual fractions increased by 19.90, 6.75 and $1.92 \%, 27.90,24.81$ and $24.63 \%$ for $2 \%, 1 \%$ and $0.5 \%$ biochar, respectively.

\section{Copper}

Figure (6) showed that speciation of soil $\mathrm{Cu}$ indicated that the main fraction is the residual. The decrease in the exchangeable, carbonate and oxide fractions was by 82.97, 77.66 and 76.44\%, 24.99, 13.21, and $9.59 \%, 33.81,31.47$ and $18.71 \%$ for $2 \%, 1 \%$ and $0.5 \%$ SCBB dosage, respectively in soil A. Cu fractions in soil $\mathrm{B}$ are dominated by residual followed by organic then oxides fractions. The decrease in the exchangeable, was by $99.53,98.60$ and $80.84 \%$, in carbonate- $\mathrm{Cu}$ was $22.31,5.48$ and $2.93 \%$ and in oxides-bound $\mathrm{Cu}$ was $23.7,15.13$ and $12.83 \%$ for $2 \%, 1 \%$ and $0.5 \%$ biochar dosage respectively. The application of SCBB to soil caused increase in organic and residual fractions by 54.66, 53.05 and $36.80 \%$ and $1.47,1.29$ and $1.59 \%$ for $2 \%, 1 \%$ and $0.5 \%$ SCBB dosage, respectively, in soil A. The increase of these fractions in soil B was by $20.93 \%$, $17.64 \%, 18.17 \%, 4.27 \%, 2.92 \%$, and $1.96 \%$ for $2 \%, 1 \%$ and $0.5 \%$ biochar dosage respectively.

These results demonstrated that exchangeable, carbonate and oxides-bound fractions of $\mathrm{Cr}, \mathrm{Zn}, \mathrm{Ni}$ and $\mathrm{Cu}$ decreased with increasing in applied rate of SCBB, while the residual and organic fraction increased. The current results agree with (Xu et al., 2014). This means that treating of the soil with biochar change soil heavy metals speciation due to change some chemical and physical properties (Yang et al., 2014). Decreasing the exchangeable fraction means decrease the available and mobile content of heavy metals. The reduction in oxides-bound fraction by addition biochar may be due the increase in soil aeration and increase soil aggregation thus encouraging microbial activity, which can solubilize fraction bound to oxides, this result in agreement with result obtained by (Nie et al., 2018). The reduction in carbonate fraction may be attribute with little drop in $\mathrm{pH}$ value after addition of SCBB with low $\mathrm{pH}$ value (6.61) to soil $\mathrm{A}$. However, the reason is not clear in soil B (Nie et al., 2018). Residual fraction is considered invalid fraction and does not easy to use by living organisms (Chen, 2005). The reason for the increase of residual and organic fractions demonstrated by some previous studies as (Yuan et al., 2016; Lu et al., 2017) who elevated that addition biochar to soil increase the nutrient elements such as $\mathrm{P}, \mathrm{Ca}$ and $\mathrm{Si}$ 
which may cause the immobilization of $\mathrm{Cr}, \mathrm{Zn}$. $\mathrm{Ni}$ and $\mathrm{Cu}$ by forming insoluble precipitation or coprecipitation.

High biochar surface area and presence of functional groups, which contain double and triple bounds, contribute to metals stabilization (Abdelhafez et al., 2014). Also, Abdel-Fattah et al. (2015) reported that biochar increases organic matter and cation exchange capacity which increase complexation of soil heavy metal ions, and thus decrease available content of heavy metals. Biochar application increases soil organic matter (Saleh et al., 2020), which stimulate transformation of the available and less available metals to residual fractions (Xu et al. 2012).

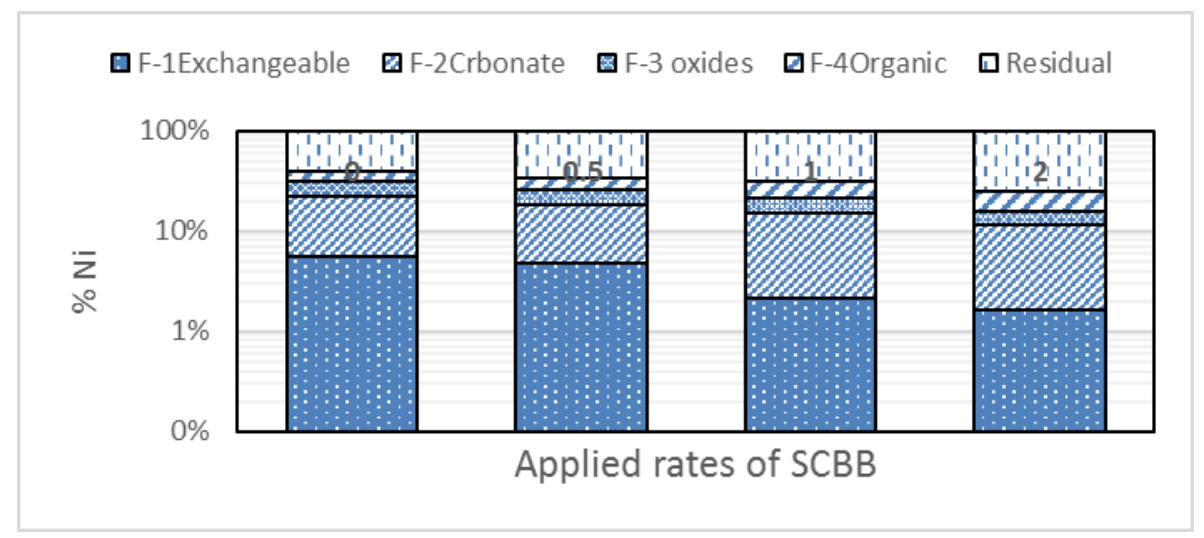

$\mathrm{Ni}$ in Soil A

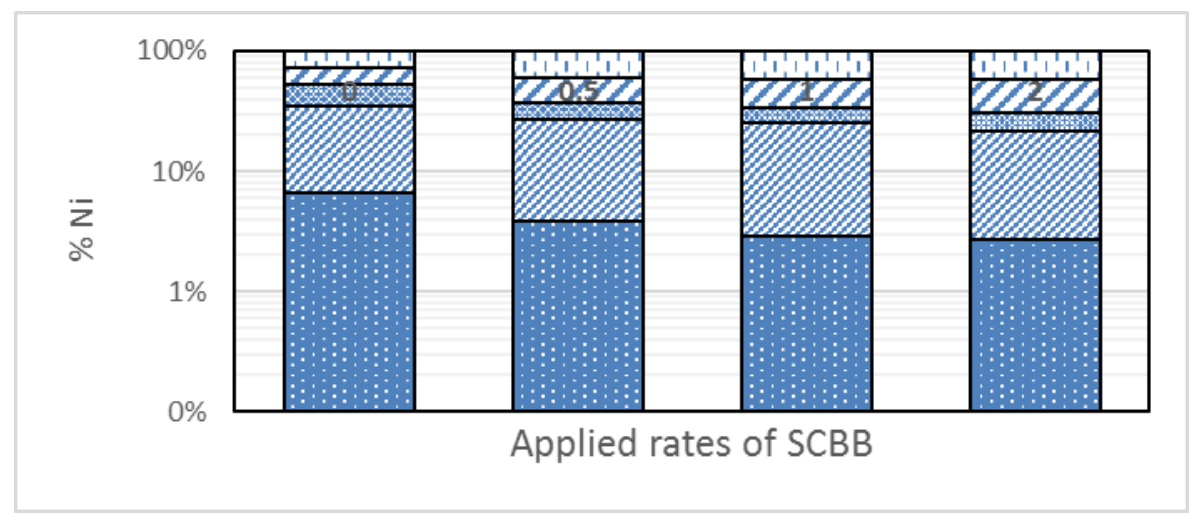

$\mathrm{Ni}$ in Soil B

Fig.5 Changes in soil nickel (Ni) fractions as result of sugarcane bagasse biochar (SCBB) application rate to soil $A$ and $B$ 

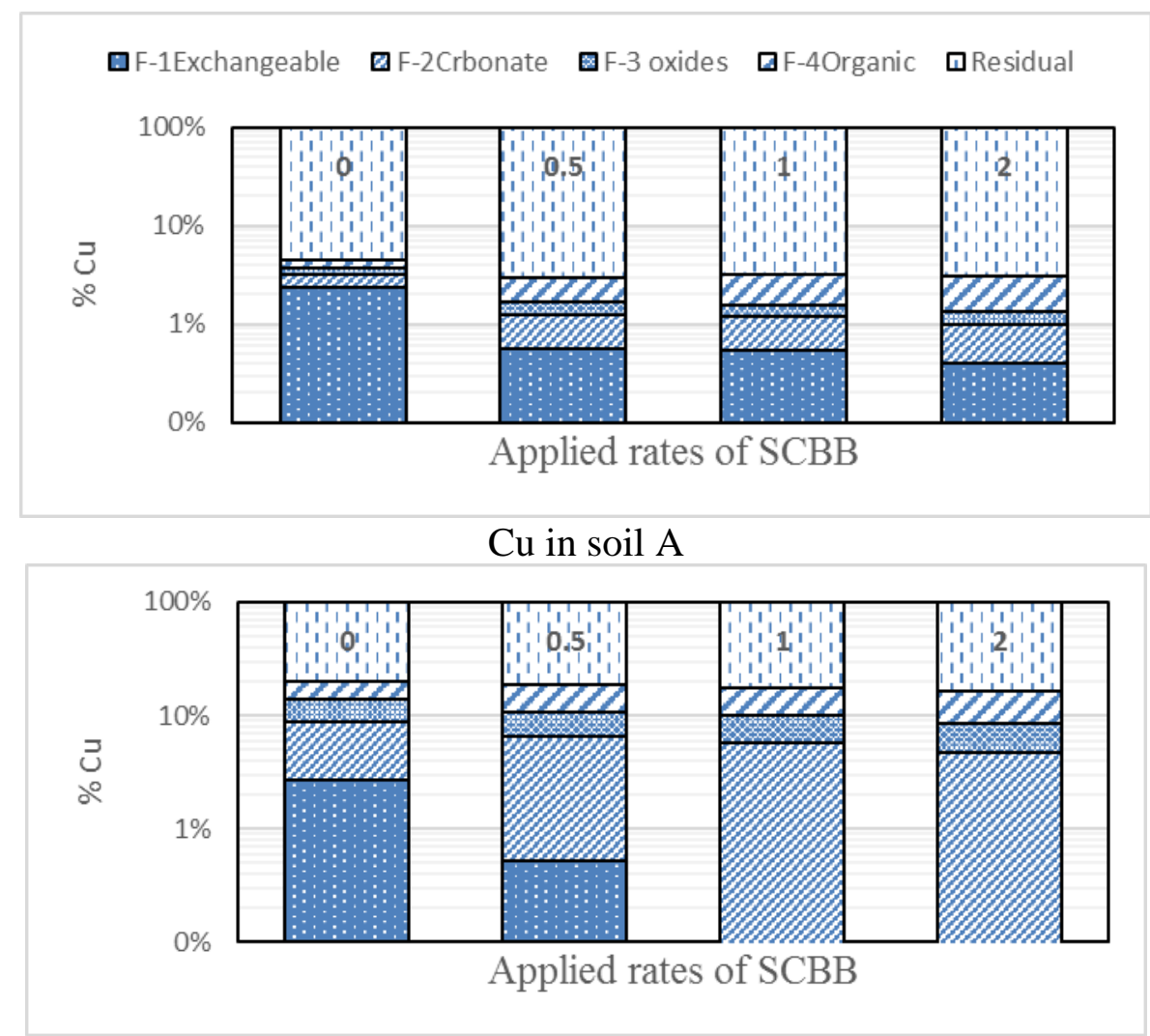

\section{$\mathrm{Cu}$ in soil B}

Fig. 6 Changes in soil zinc fractions as result of sugarcane bagasse biochar (SCBB) application rate to soils A and $B$

Effect of biochar on DTPA-extractable heavy metals in $\underline{\text { soil }}$

Fig (7) showed a decreasing in DTPA-extractable concentrations of $\mathrm{Cr}, \mathrm{Zn}, \mathrm{Ni}$ and $\mathrm{Cu}$ in soil $\mathrm{A}$ and $\mathrm{B}$ according to different dosage of biochar compared to control. The data demonstrate that the metals availability decreased with addition of SCBB that can be related to high surface area and presence of exchangeable sites, which retained these elements and decreased their bioavailability (Fellet et al., 2014). The decreasing in availability increased with increasing application rate of SCBB, which agreed with the results presented by Puga et al. (2015b) who studied the effect of different dosage of sugarcane straw biochar on availability of some heavy metals. The decreases in DTPA- extractable of $\mathrm{Cr}, \mathrm{Ni}$, and $\mathrm{Cu}$ in soil $\mathrm{B}$ was higher than in soil A, which may be due to that soil B has higher $\mathrm{pH}$ (7.88-7.96) than soil A (7.43-7.48) after plant harvest which encourage increase residual fraction (precipitation) and decrease availability (Zhu et al., 2015).
Effect of biochar treatment on plant uptake of heavy $\underline{\text { metals }}$

Tables 4 and 5 shows the concentration of $\mathrm{Cr}, \mathrm{Zn}$, $\mathrm{Cu}$ and $\mathrm{Ni}$ in shoot and root in radish plant. It obvious the decrease in heavy metals content in shoot and root of plant with increasing the addition rate of SCBB.

The percentage reduction in concentration of $\mathrm{Zn}$ in shoot were $5.40,8.63$, and $11.95 \%$ and in root 2.57 , $12.25,17.28 \%$ in soil A compared to control and by $2.16,6.32$, and $12.62 \%$ in shoot and in root was by $23.13,31.25$ and $64.06 \%$ in soil B for biochar application rates $0.5,1$ and $2 \%$, respectively.

For $\mathrm{Cu}$ the reduction concentration in shoot was by $3.17,6.25$ and $31.54 \%$, however in root was by 33.78 , 60.19 , and 74.90 in soil $\mathrm{A}$. Whereas, in soil $\mathrm{B}$, the reduction was by $1.86,13.96$, and 30.89 in shoot, 5.47, 13.57 , and $52.43 \%$ in root.

The reduction in $\mathrm{Ni}$ concentration was by 39.23 , 47.15 , and $84.66 \%$ in shoot however in root was by $42.17,66.53$ and $71.04 \%$ in soil A and by $22.41,54.35$, and $86.02 \%$ in shoot and $34.55,44.32$, and $65.21 \%$ in root of soil B with application rate of SCBB 0.5, 1 and $2 \%$ respectively. 
For $\mathrm{Cr}$ the reduction in concentration was by 19.88 , 35.02 and 53.33 in shoot, however in root was by 3.96 , 26.55 , and $43.96 \%$ in soil A and by 5.68, 34.12 and $39.79 \%$ in shoot and by $23.47,57.29$, and $66.51 \%$ in soil B for biochar treatment $0.5,1,2 \%$ respectively.

These results demonstrated the important role of biochar in reduction the concentration of $\mathrm{Zn}, \mathrm{Cu}, \mathrm{Cr}$ and $\mathrm{Ni}$ in plant, as a result of immobilization of these heavy metals in soil and reduce its bioavailability. This is in agreement with Hegab et al. (2016), Nie et al. (2018) and Zhu et al. (2015). In addition, Yang et al. (2017) who used tobacco stalk and dead pig biochars to decrease the content of $\mathrm{Cd}$ and $\mathrm{Zn}$ in tobacco plants, the results showed significant effective by the biochar application rate.

Table (6) showed that, there was a positive and significant correlation $(\mathrm{p}<0.05$ or 0.01 ) among all combinations of the studied parameters, except available after planting with total soil after planting, shoot and root of plants grown in Burg Al Arab location.

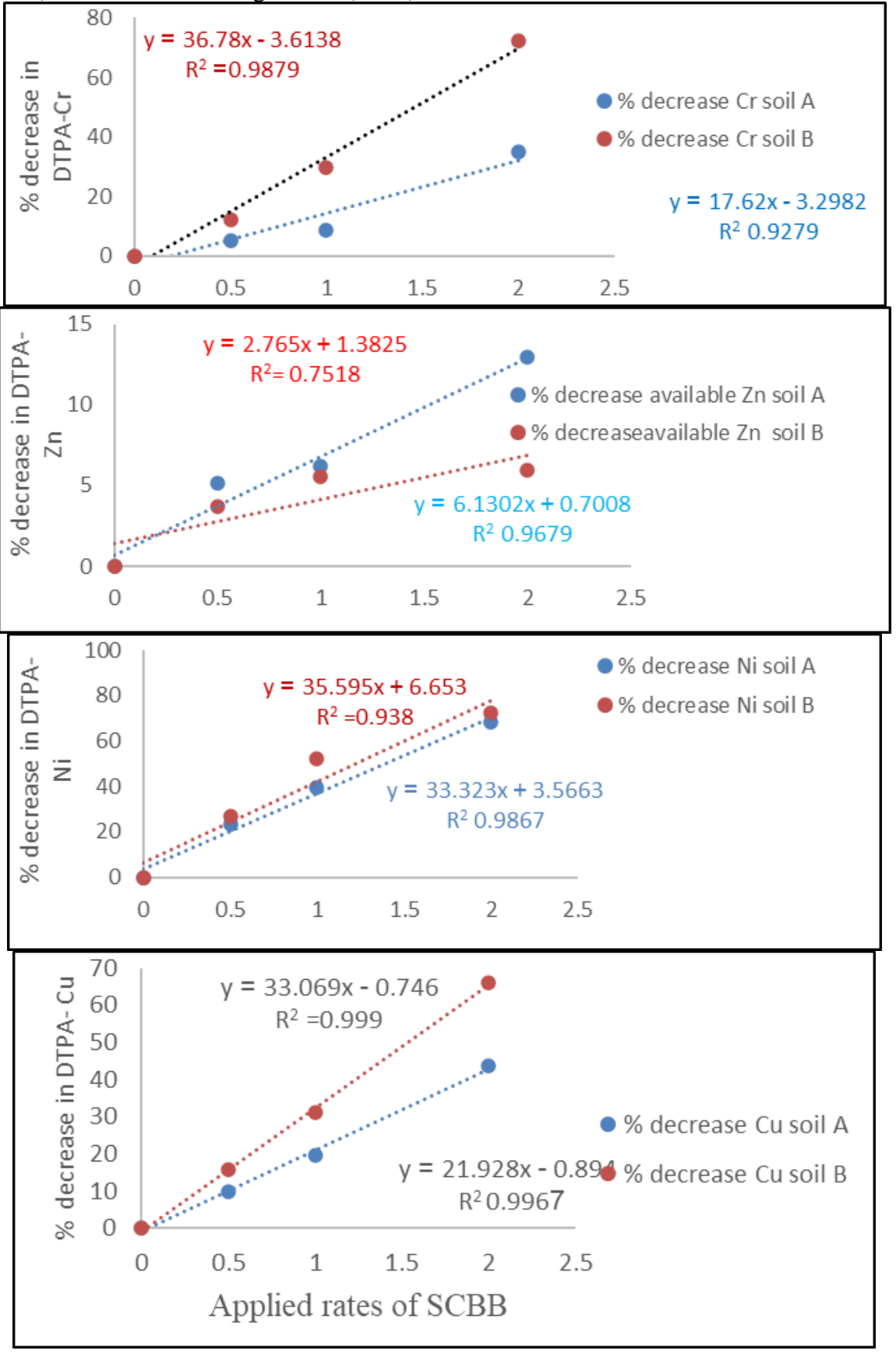

Fig 7. effect of sugarcane bagasse biochar (SCBB) on DTPA-extractable heavy metals in soils A and B 
Table 4. Effect of biochar dosage on heavy metals content in shoot of radish plant

\begin{tabular}{ccccccccc}
\hline & \multicolumn{9}{c}{ Heavy metals in radish plant shoot $(\mathrm{mg} / \mathrm{kg})$} \\
\cline { 2 - 9 } $\begin{array}{c}\text { Biochar } \\
\text { treatment } \\
\%\end{array}$ & Soil A & Soil B & Soil A & Soil B & Soil A & Soil B & Soil A & Soil B \\
\cline { 2 - 9 } & & & & & & & & \\
\hline 0 & 7.255 & 5.693 & 11.35 & 2.729 & 12.26 & 11.02 & 8.85 & 3.87 \\
0.5 & 6.863 & 5.570 & 10.99 & 2.678 & 7.45 & 8.55 & 7.09 & 3.65 \\
1 & 6.629 & 5.333 & 10.64 & 2.348 & 6.48 & 5.03 & 5.75 & 2.55 \\
2 & 6.388 & 4.974 & 7.77 & 1.886 & 1.88 & 1.54 & 4.13 & 2.33 \\
Mean & 6.784 & 5.393 & 9.94 & 2.410 & 7.02 & 7.51 & 6.46 & 3.10 \\
LSD at & 0.05 & 0.01 & 0.05 & 0.01 & 0.05 & 0.01 & 0.05 & 0.01 \\
Locations & $0.54^{*}$ & $0.75^{* *}$ & $0.63^{*}$ & $0.88^{* *}$ & $0.44^{*}$ & $0.60^{* *}$ & $0.19^{*}$ & $0.26^{* *}$ \\
SCBB & $0.77^{*}$ & $1.07^{* *}$ & $0.90^{*}$ & $1.24^{* *}$ & $0.62^{*}$ & $0.86^{* *}$ & $0.26^{*}$ & $0.36^{* *}$ \\
Interaction & $1.09^{*}$ & $1.51^{* *}$ & $1.27^{*}$ & $1.76^{\text {ns }}$ & $0.87^{*}$ & $1.21^{* *}$ & $0.37^{*}$ & $0.52^{* *}$ \\
\hline
\end{tabular}

Statistically significant differences at nsp $>0.05, * \mathrm{p}<0.05$ and $* * \mathrm{p}<0.01$.

Table 5. Effect of biochar dosage on heavy metals content in Root of radish plant (Raphanus sativus)

\begin{tabular}{ccccccccc}
\hline & \multicolumn{8}{c}{ Heavy metals in Root $(\mathrm{mg} / \mathrm{kg})$} \\
\cline { 2 - 9 } Biochar & \multicolumn{2}{c}{ Zn } & \multicolumn{2}{c}{ Cu } & \multicolumn{3}{c}{ Ni } & Cr \\
\hline$\%$ & Soil A & Soil B & Soil A & Soil B & Soil A & Soil B & Soil A & Soil B \\
\hline 0 & 8.395 & 7.464 & 21.28 & 24.68 & 25.49 & 33.66 & 11.60 & 15.29 \\
0.5 & 8.179 & 5.737 & 14.09 & 23.33 & 14.74 & 22.03 & 11.14 & 11.70 \\
1 & 7.366 & 5.131 & 8.47 & 21.33 & 8.53 & 18.74 & 8.52 & 6.53 \\
2 & 6.944 & 2.682 & 5.34 & 11.74 & 7.38 & 11.71 & 6.50 & 5.12 \\
Mean & 7.721 & 5.253 & 14.54 & 21.27 & 14.78 & 21.28 & 9.44 & 9.91 \\
LSD at & 0.05 & 0.01 & 0.05 & 0.01 & 0.05 & 0.01 & 0.05 & 0.01 \\
Locations & $0.83^{*}$ & $1.15^{* *}$ & $0.88^{*}$ & $1.22^{* *}$ & $0.56^{*}$ & $0.77^{* *}$ & $0.42^{*}$ & $0.58^{\text {ns }}$ \\
SCBB & $1.17^{*}$ & $1.62^{* *}$ & $1.24^{*}$ & $1.72^{* *}$ & $0.79^{*}$ & $1.10^{* *}$ & $0.59^{*}$ & $0.82^{* *}$ \\
Interaction & $1.65^{*}$ & $2.29^{* *}$ & $1.76^{*}$ & $2.44^{* *}$ & $1.12^{*}$ & $1.55^{* *}$ & $0.83^{*}$ & $1.16^{* *}$ \\
\hline
\end{tabular}

Statistically significant differences at nsp $>0.05,{ }^{*} \mathrm{p}<0.05$ and $* * \mathrm{p}<0.01$.

Table 6. Pearson correlation between measurements of elements in soil A and soil B

\begin{tabular}{|c|c|c|c|c|}
\hline Soil B Soil A & $\begin{array}{c}\text { Total after } \\
\text { planting }\end{array}$ & $\begin{array}{c}\text { DTPA-extracted } \\
\text { after planting }\end{array}$ & Shoot & Root \\
\hline $\begin{array}{l}\text { Total soil after } \\
\text { planting }\end{array}$ & & 0.02 & $0.97 * *$ & $0.95^{* *}$ \\
\hline $\begin{array}{l}\text { DTPA-extracted after } \\
\text { planting }\end{array}$ & $0.48^{*}$ & & 0.22 & 0.06 \\
\hline Shoot & $0.97 * *$ & $0.63 * *$ & & $0.93 * *$ \\
\hline Root & $1.00 * *$ & $0.48 *$ & $0.98 * *$ & \\
\hline
\end{tabular}

Statistically significant differences at nsp $>0.05, * \mathrm{p}<0.05$ and $* * \mathrm{p}<0.01$

\section{Conclusion}

Sugarcane bagasse biochar (SCBB) is a good tool to immobilize heavy metals in soil through changing their fractions in soil. In this study exchangeable, carbonate fractions and fractions bound to oxides for $\mathrm{Cr}, \mathrm{Zn}$. Ni and $\mathrm{Cu}$ decreased with increase in biochar dosage, however the residual and organic fraction was increased. The effect of biochar is related to its high surface area and presence of functional groups, which contain double and triple bounds, contribute to metals stabilization. Increase biochar rate significantly reduced the amount of DTPA - extracted metals in soil. It is also a clear that concentration of elements in shoot and root in radish plant significantly decreased with increase biochar dosage. 


\section{REFERENCES}

Abd El-Fattah, M.K and A.M. Helmy. 2015. Assessment of water quality of wastewaters of Bahr El-Baqar, Bilbies and El-Qalyubia drains in east delta, Egypt for irrigation purposes. Egypt J. Soil Sci. 55: 287-302.

Abd El-Fattah, T.M., M.E. Mahmoud, S.B. Ahmed, M.D. Huff, J.W. Lee and S. Kumar. 2015. Biochar from woody biomass for removing metal contaminants and carbon sequestration. J. Ind. Eng. Chem. 22: 103 -109.

Abdelhafez, A.A., J. Li and M.H.H. Abbas. 2014. Feasibility of biochar manufactured from organic wastes on the stabilization of heavy metals in a metal smelter contaminated soil. Chemosphere. 117: 66-71.

Agrafioti, E., G. Bouras, D. Kalderis and E. Diamadopoulos. 2013. Biochar production by sewage sludge pyrolysis. J. Anal. Appl. Pyrolysis. 101: 72-78.

Alghobar, M.A and S. Suresha. 2016. Effect of wastewater irrigation on growth and yield of rice crop and uptake and accumulation of nutrient and heavy metals in soil. Appl.Ecol. Environ. Sci.4 : 53-60.

Amonette, J.E and S. Joseph. 2009. physical properties of biochar. London streting, AV. In Lehman., Joseph, S, (Eds). Biochar for environment Management. PP: 13- 29.

Black, C.A. 1965. Methods of soil analysis. Part I, American Society of Agronomy. Madison, Wisconsin, USA. 1572 p.

Cao, X., L. Ma, B. Gao and W. Harris. 2009. Dairy-manure derived biochar effectively sorbs lead and atrazine. Environ. Sci. Technol. 43: 3285-3291.

Cao, X., X. Wei, G. Dai and Y. Yang. 2011. Combined pollution of multiple heavy metals and their chemical immobilization in contaminated soils: a review. Chin. J. Environ. Eng. 5: 1441-1453.

Chaosheng, Z., L. Liu, M. Zhao, H. Rong and Y. Xu. 2018. The environmental characteristics and applications of biochar. Environ. Sci. Pollut. Res. 25: 21525 - 21534.

Chauhan, M.K., V.S. Chaudhary and S.K. Samar. 2011. Life cycle assessment of sugar industry: Areview. Renew. Sust. Energ. Rev.15: 3445-3453.

Chen, M. 2005. Study on fraction and bioavailability of heavy metal elements in sewage sludges. Nanjing: HoHai University.

Davies, B.E. 1993. Radish as an indicator plant for derelict land: Uptake of zinc at toxic concentrations. Commun. Soil Sci. Plant Anal. 24: 1883-1895.

EL-Bady, M.S.M. 2014. Spatial Distribution of some Important Heavy Metals in the Soils South of Manzala Lake in Bahr El-Baqar Region, Egypt . Nova J. Eng. Appl. Sci. 2: 1- 15.

El-Damarawy, Y.A., M.E. Saleh, F.F. Assad, A.A. AbdelSalam and R.A. Youssef. 2017. Adsorption of Lead onto a Waste Biomaterial- Biochar. Nat. Sci.15. http://www.sciencepub.net/nature.
El-Gamal, E., M. Saleh, I. Elsokkary, M. Rashad and M. Abd El-Latif. 2017. Comparison between Properties of Biochar Produced by Traditional and Controlled Pyrolysis. Alex. Sci . Exch. J. 38: 412- 425.

El-Mashad, H.M., W.K.P. van Loon, G. Zeeman, G.P. A. Bot and G. Lettinga. 2003. Reuse potential of agricultural wastes in semi-arid regions: Egypt as a case study. Rev. Environ. Sci. Biotechnol. 2: 53-66.

Fellet, G, M. Marmiroli and L. Marchiol. 2014. Elements uptake by metal accumulator species grown on mine tailings amended with three types of biochar. Sci. Total Environ. 468: 598-608.

Hammer, Ø., D.A.T. Harper and P.D. Ryan. 2020. Paleontological statistics software package Palaeontologia Electronica. 4 : 9-16. for education and data analysis.

Harvey, O.R., B.E. Herbert, R.D. Rhue and L.J. Kuo. 2011. Metal interactions at the biochar-water interface: energetics and structure-sorptionrelationships elucidated by flow adsorption microcalorimetry. Environ. Sci. Technol. 45:5550-5556.

Hassan, I.A., N.B. Bell, M.R. Ashmore, L. Cotrozzi, N.S. Haiba, J.M. Basahi, A. Summan, T. Almeelbi and I.M. Ismail. 2018. Radish (Raphanus sativus L.) CultivarSpecific Response to O3: Patterns of Biochemical and Plant Growth Characteristics. Clean - Soil Air Water. 46: 1800124 (1-9).

Hegab, R.H., D. Eissa, A. Abou-Shady and O. Abdelmottaleb. 2016. Effect of biochar addition on soil properties and carrot productivity grown in polluted soils. Egypt J. Desert Res. 66: 327- 350.

Jones, J.B. 1989. Plant tissue preparation for elemental assay in soil testing and plant analysis laboratory manual. Benton laboratories, Inc. Athens, Georgia.

Lehmann, J and S. Joseph. 2009. Biochar for environmental management. Science and Technology Earthscan, Ltd., London.

Lindsay, W.L and W.A. Norvell. 1978. Development of a DTPA Soil Test for Zinc, Iron, Manganese, and Copper. SSSAJ. $42:$ 421-428.

Lu, K., X. Yang, G. Gielen, N. Bolan, Y.S. Ok, N. K. Niazi, S. Xu, G. Yuan, X. Chen and X. Zhang. 2017. Effect of bamboo and rice straw biochars on the mobility and redistribution of heavy metals $(\mathrm{Cd}, \mathrm{Cu}, \mathrm{Pb}$ and $\mathrm{Zn})$ in contaminated soil. J. Environ. Manage. 186:285- 292.

Mehmood, T., I. Bibi, M. Shahid, N.K. Niazi, B. Murtaza, H. Wang, Y.S. Ok, B. Sarkar, M.T. Javed and G. Murtaza. 2017. Effect of compost addition on arsenic uptake, morphological and physiological attributes of maize plants grown in contrasting soils. J. Geochem. Explor. 178: 83-91.

Mench, M., N. Lepp, V. Bert, J.P. Schwitzguébel, S.W. Gawronski, P. Schöder and J. Vangronsveld. .2010. Successes and limitations of phytotechnologies at field scale: outcomes, assessment and outlook from COST action 859. J. Soils Sediments. 10: 1039-1070. 
Meng, F., G. Yuan, J. Wei, D. Bi, Y.S. Ok and H. Wang. 2017. Humic substances as a washing agent for Cdcontaminated soils. Chemosphere. 181:461-467.

Nakhla, D.A and S. El Haggar. 2014. Environmentally blanced Sugar cane industry. http://uest.ntua.gr > conference. http://dx.doi.org/10.1016/j.biortech.2014.08.108.

Nandiyanto, A., R. Oktiani and R. Ragadhita. 2019. How to read and interpret FTIR spectroscopy of organic materials. Indones. J. Sci. Technol. 4: 97-118.

Niazi, N.K., I. Bibi, A. Fatimah, M. Shahid, M.T. Javed, H. Wang, Y.S. Ok, S. Bashir, B. Murtaza and Z.A. Saqib. 2017. Phosphate-assisted phytoremediation of arsenic by Brassica napus and Brassica juncea: morphological and physiological response. Int. J. Phytoremediation. 19: 670678.

Nie, Ch., X. Yang, N. Niazi, X. Xu, Y. Wen, J. Rinklebe, Y. Ok, S. Xu and H. Wang. 2018. Impact of sugarcane bagasse - derived biochar on heavy metal availability and microbial activity: A field study. Chemosphere. 200: 274282.

Novotny, E.H., C.M.B. D.F. Maia, M.T.D.M. Carvalho and B.E. Madari. 2015. Biochar: Pyrogenic Carbon for Agricultural Use - A Critical Review. Rev. Bras. Cienc. Solo.39: 321- 344.

Puga, A., C.A. Abreu, L.C.A. Melo and L. Beesley. 2015a. Biochar application to a contaminated soil reduces the availability and plant uptake of zinc, lead and cadmium. J. Environ Manage. 159:86- 93.

Puga, A.P., C. A. Abreu, L. C. A. Melo, J. Paz-Ferreiro and L. Beesley. 2015b. Cadmium, lead, and zinc mobility and plant uptake in a mine soil amended with sugarcane straw biochar. Environ. Sci. Pollut. Res. 22: 1760617614

Rajkovich, S., A. Enders, K. Hanley, C. Hyland, A. R. Zimmerman and J. Lehmann. 2012. Corn growth and nitrogen nutrition after additions of biochars with varying properties to a temperate soil. Biol. Fertil. Soils. 48: 271284.

Rashad, F.M., M. H. El Kattan, H. M. Fathy, D. A. Abd ElFattah, M. El Tohamy and A.A. Farahat. 2019. Recycling of agro-wastes for Ganoderma lucidum mushroom production and Ganoderma post mushroom substrate as soil amendment. Waste Management. 88: 147- 159.

Sahu, J. N., J. Acharya and B. C. Meikap. 2010. Optimization of production conditions for activated carbons from Tamarind wood by zinc chloride using response surface methodology. Bioresour. Technol, 101: 1974 - 1982.

Saleh, M.E and R.M.R. Hedia. 2018. Mg-Modified Sugarcane Bagasse Biochar for Dual Removal of Ammonium and Phosphate Ions from Aqueous Solutions. Alex. Sci . Exch. J. 39: 74-91.

Saleh, M.E, A.A. El-Refaey and Y.A. Eldamarawy. 2020. Effect of Bone Char application in Reducing $\mathrm{CO} 2$ Emission and Improvement Organic Matter in Calcareous Soils. Egypt. J. Soil. Sci. 60: 365-375 .

Saleh, M.E., A.H. Mahmoud and A.A. El-Refaey. 2014. Removal of cadmium from aqueous solution by biocharsderivedfrom peanut hull and wheat straw. Adv. Environ. Biol. 8: 399-409.

Samsuri, A.W., F. Sadegh- Zadeh and B. J. Seh- Bardan. 2014. Characterization of biochars produced from oil palm and rice husks and their adsorption capacities for heavy metals. Int. J. Environ. Sci. Technol. 11: 967-976.

Song, W and M. Guo. 2012. Quality variations of poultry litter biochar generated at different pyrolysis temperatures. J. Anal. Appl. Pyrolysis. 94: 138-145.

Srinivasan, P., A.K. Sarmah, R. Smernik, O. Das, M. Farid and W. A. Gao. 2015. Feasibility study of agricultural and sewage biomass as biochar, bioenergy and biocomposite feedstock: production, characterization and potential applications. Sci. Total Environ. 512: 495- 505.

Steel, R.G.D., J. H. Torrie and D.A. Dickey. 1997. Principles and rocedures of statistics: a biometrical approach. 3rd ed. New York: McGraw Hill.

Tang, J., W. Zhu, R. Kookana and A. Katayma. 2013. Cheracteristics of biochar and its application in remediation contaminated soil. J. Biosci. Bioeng. 116: 653- 659 .

Tessier, A., P. G. C.Campbell and M. Blsson. 1979. "Sequential extraction procedure for the speciation of particulate trace metals," Analytical Chemistry. 52 (1): 45- 53.

Trakal, L., D. Bingol, M. Pohorelý, M. Hruska and M. Komarek. 2014. Geochemical and spectroscopic investigations of $\mathrm{Cd}$ and $\mathrm{Pb}$ sorption mechanisms on contrasting biochars: engineering implications. Bioresour. Technol. 171:442- 451 .

Ure, A.M. 1995. In "Methods of Analysis for Heavy Metals in Soils".

Heavy Metals in Soils. (Alloway, B. J. Ed.). Blacke Academic and

Professional, An Imprint of Chapman and Hall, Wester Cleddens Road, Bishopbriggs, Glasgow G64 2NZ, UK. 58- 102.

Wali, A., G. Coinet, M. Khadhraoui and M. Ksibi. 2013. Trace metals in surface soil contamination by release of Phosphate industry in the surroundings of Sfax-Tunisia. Environ. Res. Eng. Manag. 65 : 20- 30.

WHO.1996. "Permissible limits of heavy metals in soil and plants" World health organization.

Xu, C., X. B. Lin, W. U. Qi-Tang, H. T. Tang, Y. L. Liao and X. B. Qin .2012. Impacts of biochar on availability of heavy metals and nutrient content of contaminated soil under waterlogged conditions. J. Soil Water Conserv. 26 : 194- 199.

Xu, N., D. Lin, Y. Xu, Z. Xie, X. Liang and W. Guo. 2014. Adsorption of aquatic $\mathrm{Cd} 2+$ by biochar obtained from corn stover. J. Agro-Environ. Sci.33: 958- 964.

Yang, G., L. Yan and L. Wu. 2014. Concentration and health risk of heavy metals in topsoil of paddy field of Chengdu Plain. Environ. Chem. 32 : 269- 275.

Yang, X., K. Lu, K. McGrouther, L. Che, G. Hu, Q. Wang, X. Liu, L. Shen, H. Huang, Z. Ye and H. Wang. 2017. Bioavailability of $\mathrm{Cd}$ and $\mathrm{Zn}$ in soils treated 
with biochars derived from tobacco stalk and dead pigs. J. Soils Sediments. 17: 751- 762.

Yuan, H, T. Lu, Y. Wang, Y. Chen and T. Lei. 2016. Sewage sludge biochar:

nutrient composition and its effect on the leaching of soil nutrients.Geoderma. 267:17-23.

Zhang, W., S. Mao, H. Chen, L. Huang and R. Qiu. 2013. $\mathrm{Pb}$ (II) and $\mathrm{Cr}$ (VI) sorption biochars pyrolyzed from the municipal wastewater sludge under different heating conditions. Bioresour. Technol. 147:545- 552.
Zhang, X. 2017. Effect of bamboo and rice straw biochars on the mobility and redistribution of heavy metals $(\mathrm{Cd}, \mathrm{Cu}$, $\mathrm{Pb}$ and $\mathrm{Zn}$ ) in contaminated soil. J. Environ. Manag. 186: 285-292.

Zhou, H., W.T. Yang, X. Zhou, L. Liu, J. F. Gu, W. L. Wang, J.L. Zou, T. Tian, P.Q. Peng and B.H. Liao. 2016. Accumulation of heavy metals in vegetable species planted in contaminated soils and the health risk assessment. Int. J. Environ. Res. Public Health. 13 : 1-12.

Zhu, Q., J. Wu, L. Wang, G. Yang and X. Zhang. 2015. Effect of Biochar on Heavy Metal Speciation of Paddy Soil. Water Air Soil Pollut. 226: 1-10.60. DOI 10.1007/s40710-015-0063-9.

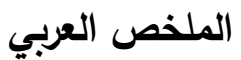

\section{تأثير الفحم الحيوي على السلوك الكيميائي للعناصر الثقيلة}

\section{وامتصاص نبات الفجل النامي في أراضي ملوثة}

$$
\text { ليلى رمضان سالم، ماهر السيد صالح، دينا سليمان أبو العينين }
$$

لانخفاض التركيز المستخلص كيميائيا لكل من الزنك والنيكل

والنحاس والكروم مع زيادة معدل الفحم الحيوي المضاف

للتربة انخفضت تركيزات المعادن الثقيلة في أوراق وجذور

نبات الفجل مع زيادة جرعة الفحم الحيوي. وترى الدراسة أن

كل من مساحة السطح العالية والمجموعات الوظيفية السطحية للفحم الحيوي قد لعبت دورا هاما في تتبيت واستقرار المعادن الثتيلة في الصورة العضوية والمتبقية في التربة وهي الأكثر ثباتا بالتربة.

الكلمات المفتاحية : الفحم الحيوى لتفل قصب السكر,

الأراضى الملوثة, الصور الكيميائية للمعادن الثقيلة, التيسر الحيوى
يهدف هذا البحث إلى دراسة تأثير الفحم الحيوي لتفل قصب السكر على السلوك الكيميائي لبعض المعادن الثقيلة، الزنك والنيكل والكروم والنحاس، وذلك من خلال تجربة التعرف على الصور الكيميائية لهذه المعادن في تربة ملوثة من محافظة الثرقية (التربة أ) والتي تروى بشكل رئيسي بمياه الصرف الصحي من مصرف بحر البقر، و(التربة ب) من برج العرب، محافظة الإسكندرية، بالإضافة إلى ذلك تمت دراسة المحتوى المستخلص كيميائيا لهذه المعادن في التربة بعد معاملة التربة بمعاملات مختلفة من الفحم الحيوي (0. •و او ب\%)، عن طريق تجربة الزراعة في أصص لنبات الفجل كمؤشر حيوي، وأظهرت النتائج أن المعادن الموجودة في الصورة المتبادلة والصورة المرتبطة بالكربونات والمرتبطة بالأكاسيد قد انخفضت مع زيادة جرعة الفحم الحيوي، وعلى لئ العكس من ذلك كانت الصورة العضوية والمتبقية؛ وكنتيجة 